SOSIOLIUM

\title{
KREATIVITAS GURU IPS DALAM PENGEMBANGAN MEDIA PEMBELAJARAN PADA SMP NEGERI 2 SEMARANG DAN MTS NEGERI 1 SEMARANG
}

\author{
Ananda Sekar Tunjung, Arif Purnomo ${ }^{\bowtie}$
}

Prodi Pendidikan IPS, Fakultas Ilmu Sosial, Universitas Negeri Semarang, Indonesia

\section{Info Artikel}

Sejarah Artikel:

Disubmit: Mei 2020

Direvisi: Juni 2020

Diterima: Juli 2020

\section{Keywords:}

Development of learning media, social studies subjects

\begin{abstract}
Abstrak
Guru mempunyai peran penting dalam pelaksanaan pembelajaran. Oleh karena itu harus bisa menggunakan media pembelajaran IPS dan dapat mengembangkan media pembelajaran IPS dengan kreativitas yang dimiliki agar pembelajaran dapat tercapai secara maksimal. Metode penelitian yang digunakan adalah metode kualitatif. Hasil penelitian menunjukan bahwa (1) medoa pembelajaran yang digunakan oleh guru yaitu LCD, peta, globe, gambar, video, puzzle, mahkota naget dan couple card (2) kreativitas guru IPS dalam pengembangan media pembelajaran dilakukan melalui kolaborasi dengan teman sejawat, guru mengembangkan media mencari di internet, dan guru mengembangkan media dengan memanfaatkan bahan-bahan yang ada di lingkungan (3) evaluasi kebermanfaatan dengan media pembelajaran yaitu media dapat memperjelas materi, media menyebabkan motivasi belajar anak meningkat, dan media dapat meningkatkan hubungan interaksi antara guru dan siswa.
\end{abstract}

\section{Abstract}

The teacher has an important role in the implementation of learning. Therefore, it must be able to use social media learning and be able to develop social media learning with creativity that is owned so that learning can be achieved optimally. The research method used is a qualitative method. The results showed that (1) the instructional media used by the teacher were LCD, maps, globe, pictures, video, puzzles, naget crowns and couple card (2) creativity of social studies teachers in developing learning media is done through collaboration with peers, teachers develop media searching on the internet, and teachers develop media by utilizing materials in the environment (3) evaluation of the usefulness of learning media that is media can clarify the material, the media cause childrens learning motivation to increase, and the media can improve the interaction relationship between teachers ans students.

E-mail: arifpurnomo@mail.unnes.ac.id 


\section{PENDAHULUAN}

Sekolah merupakan salah satu lembaga pendidikan formal untuk mencapai tujuan pendidikan nasional. Sebagaimana tercantum dalam undang-undang sistem pendidikan nasional No. 20 Tahun 2003 menyatakan tujuan "pendidikan nasional yaitu untuk mengembangkan potensi peserta didik agar menjadi manusia yang beriman dan bertakwa kepada Tuhan Yang Maha Esa, berakhlak mulia, sehat berilmu, cakap, kreatif, mandiri dan menjadi warga negara yang demokratis serta bertanggung jawab.

Ada beberapa faktor yang mempengaruhi adanya pendidikan yang berkualitas, salah satu faktornya yaitu guru. Sebagai perancang dan pelaksana kegiatan pembelajaran, guru adalah seseorang yang secara langsung mengetahui bagaimana proses pembelajaran terjadi. Proses belajar mengajar merupakan inti dari proses pendidikan secara keseluruhan dengan guru sebagai pemegang peranan utama.

Salah satu yang mempengaruhi dalam proses mengajar dikelas yakni guru yang kreatif dan professional sebagai penunjang pencapaian hasil belajar yang optimal. Dikaitkan dengan kreativitas guru harus menciptakan suatu strategi mengajar yang benar-benar baru dan orisinil (ciptaan sendiri) sehingga menghasilkan kreavitas yang baru bagi pembelajaran di sekolah. Sesuai undang-undang No. 14 Tahun 2005 tentang guru dan dosen bahwa "guru harus memiliki kompetensi pedagogik", dimana guru harus mampu menguasai proses pembelajaran, dalam artian guru menguasai strategi pembelajaran dan mampu membuat media pembelajaran yang inovatif sesuai kebutuhan dalam proses kegiatan pembelajaran di kelas.

Media pembelajaran adalah sebuah alat yang berfungsi untuk menyampaikan pesan pembelajaran. Menurut Undang-Undang No.20 Tahun 2003 Pasal 1 ayat 20 media pembelajaran merupakan salah satu komponen pendukung keberhasilan proses belajar mengajar. Dengan adanya media kerumitan bahan yang akan disampaikan kepada siswa dapat disederhanakan dengan bantuan media. Media dapat mewakili apa yang kurang mampu guru ucapkan melalui kata-kata atau kalimat tertentu.
Dengan demikian, siswa lebih mudah mencerna bahan disbanding tanpa bantuan media.

Mata pelajaran Ilmu Pengetahuan Sosial merupakan mata pelajaran yang mempelajari berbagai rumpun ilmu sosial yang dijadikan satu kesatuan secara terpadu. Pada jenjang SMP materi IPS mencakup Sejarah, Geografi, Sosiologi dan Ekonomi.

Menurut Nisa (2017:61) IPS merupakan integrasi dari berbagai cabang ilmu-ilmu sosial seperti: sosiologi, sejarah, geografi, IPS, politik, hukum, dan budaya. IPS dalam konteks Sekolah Menengah Pertama (SMP) mempelajari sosiologi, sejarah, geografi dan ekonomi.

Purnomo (2016:14) Tujuan pendidikan IPS adalah untuk mendidik dan member bekal kemampuan dasar kepada siswa untuk mengembangkan diri sesuai dengan bakat, minat, kemampuan dan lingkungannya, serta berbagai bekal siswa untuk melanjutkan pendidikan ke jenjang yang lebih tinggi. Pada jenjang SMP ini siswa diberi bekal supaya mempunyai arahan untuk meneruskan ke jenjang yang lebih tinggi. Masa peralihan inilah sangat penting pemberian bekal untuk dapat bersosialisasi dalam lingkungan masyarakat.

Keberadaan media pembelajaran dalam sebuah sekolah akan mempengaruhi pula terhadap kualitas pembelajaran untuk mencapai optimal. Kekurangan penerapan media pembelajaran oleh guru IPS yaitu cenderung hanya menggunakan media pembelajaran yang tersedia di sekolah, sehingga jarang dikaitkan dengan objek yang akrab dengan siswa.

Kualitas pembelajaran dapat dilihat dari kreativitas guru dalam mengajar. Pada pembelajaran guru tidak hanya sekedar menyampaikan materi saja, namun tanggungjawab dimana siswa dapat memahami materi yang disampaikan sehingga dapat mencapai tujuan pendidikan yang sudah ditentukan.

Guru mempunyai peran untuk menciptakan pembelajaran yang kreatif, melalui perencanaan yang dilakukan dengan membuat perangkat pembelajaran, salah satunya membuat media pembelajaran sendiri.

Keuntungan pembuatan media pembelajaran sendiri yaitu guru sudah paham dan mengerti terlebih dahulu sebelum 
menyampaikan kepada siswa. Sedangkan bagi siswa akan lebih mudah dalam pembelajaran tidak membosankan dan jenuh dengan mempelajari materi-materi.

Berdasarkan uraian di atas kreativitas guru dalam pengembangan media pembelajaran IPS itu sangatpenting. Melalui media pembelajaran memungkinkan siswa dapat mempelajari materi secara efektif dan evisien. Upaya yang dilakukan dalam rangkan mengembangkan media pembelajaran yang kreatif yaitu peneliti melakukan penelitian tentang "Kreativitas Guru IPS Dalam Pengembangan Media Pembelajaran Pada SMP Negeri 2 Semarang dan MTs Negeri 1 Semarang".

\section{METODOLOGI PENELITIAN}

Pendekatan yang dilakukan dalam penelitian ini adalah melalui pendekatan kualitatif. Bogdan dan Taylor dalam (Moleong, 2017:4) mendefinisikn bahwa metodologi kualitatif sebagai prosedur penelitian menghasilkan data deskriptif berupa kata-kata tertulis atau lisan dari orang-orang dan perilaku yang diamati. Latar penelitian ini di SMP Negeri 2 Semarang dan MTs Negeri 1 Semarang. Fokus penelitian ini adalah kreativitas guru dalam menggunakan media pembelajaran, kreativitas guru dalam mengembangkan media pembelajaran dan kebermanfaatan media pembelajaran yang digunakan oleh guru. Sumber data dalam penelitian ini adalah informan, kenyataan yang diamati atau hasil observasi dan dokumen. Informan utama pada penelitian ini adalah guru IPS, informan pendukung yaitu siswa.

Teknik pengumpulan data yang digunakan adalah observasi partisipasif, wawancara dan dokumen. Kegiatab observasi yang dilakukan oleh peneliti yaitu mengikuti pembelajaran di dalam kelas sebagai pendengar dan mengamati guru mengajar. Guna mendapatkan data yang akurat maka peneliti melakukan wawancara mendalam terhadap guru dan dikroscek ke siswa. Peneliti juga mengambil data berupa dokumentasi yang meliputi Rencana Perencanaan Pembelajaran (RPP), media pembelajaran dan foto kegiatan. Pada penelitian ini menggunakan triangulasi sumber dan triangulasi teknik. Analisis yang digunakan pada penelitian ini menggunakan analisis model interaktif. Analisis interaktif terdiri atas tiga alur yaitu pengumpulan data, reduksi data, penyajian data dan penarikan kesimpulan.

\section{HASIL DAN PEMBAHASAN}

\section{Penggunaan Media Pembelajaran IPS}

Pada pembelajaran sangat diperlukan membuat perencanaan berupa RPP, pada RPP ini tercantum media pembelajaran yang akan digunakan dalam menyampaikan materi, dan dalam lampiran RPP tercantum materi ajar yang akan disampaikan. Guru yang membuat perencanaan pembelajaran dengan matang akan terlihat dalam proses pembelajaran menjadi terarah.

Menurut Heinich yang dikutip oleh Azhar Arsyad (2011:4) media pembelajaran adalah perantara yang membawa pesan atau informasi bertujuan instruksional atau mengandung maksud-maksud pengajaran antara sumber dan penerima. Sedangkan menurut Sukmadinata (Tatang M. Amirin, 2010: 41) menjelaskan bahwa media pembelajaran merupakan segala macam bentuk perangsang dan alat yang disediakan guru untuk mendorong siswa belajar. Hal ini berarti media pembelajaran yang disediakan oleh guru dapat membantu merangsang pikiran, perasaan dan kemauan peserta didik sehingga dapat mendorong terciptanya proses belajar pada peserta didik.

Media pembelajaran yang digunakan oleh guru IPS pada SMP N 2 Semarang dan MTs N 1 Semarang seperti power point, video dan gambar. Adapun media yang dibuat oleh guru IPS yaitu puzzle, mahkota naget, jam putar ASEAN, dan couple card.

Guru sebelum menggunakan media pembelajaran melakukan persiapan terlebih dahulu seperti mempertimbangkan pemilihan media. Hal ini sebagaimana yang dikemukakan ibu Sri, guru IPS di SMP N 2 Semarang sebagai berikut "Dalam menggunakan media pembelajaran, saya mempertimbangkan faktor kemudahan didapat, media yang mempermudah siswa dalam memahami materi. Dapat digunakan dimana saja dan kapan saja. Selain itu dalam menggunakan media pembelajaran saya menyesuaikan dengan RPP" (wawancara 2 Oktober 2019). 
Prinsip pokok yang harus diperhatikan dalam penggunaan media pada setiap kegiatan belajar mengajar adalah media digunakan dan diarahkan untuk mempermudah siswa belajar dalam upaya memahami materi pelajaran. Menurut Sanjaya (2010:173-174) ada sejumlah prinsip yang harus diperhatikan dalam penggunaan media pembelajaran yaitu

a. Media yang digunakan guru harus sesuai dan diarahkan untuk mencapai tujuan pembelajaran.

Tujuan pembelajaran menggambarkan proses dan hasil belajar yang diharapkan dicapai oleh siswa sesuai dengan kompetensi dasar. Media tidak hanya untuk mempermudah guru dalam menyampaikan materi pembelajaran dan sebagai alat bantu hiburan bagi siswa tetapi juga membantu siswa belajar sesuai dengan tujuan yang ingin dicapai.

Ibu Sri dan ibu Heppy guru IPS di SMP N 2 Semarang berpendapat siswa mampu mengingat materi yang diberikan oleh guru ketika proses pembelajaran yang dilakukan menggunakan media pembelajaran. Misalnya pada saat materi geografi ibu Heppy memilih media puzzle karena memungkinkan siswa menjadi aktif, juga dapat menjadi alat permainan edukatif yang dapat memberikan pengetahuan dan mengembangkan kemampuan anak. Respon siswa untuk media puzzle sangat antusias dan merasa tertantang untuk menggabungkan satu persatu media puzzle tersebut. Dalam menggabungkan media puzzle ini juga diperlukan adanya ketelitian dari siswa agar dapat menggabungkan dengan tepat. Hal tersebut juga yang mendorong guru untuk menggunakan media tersebut untuk melatih ketelitian dan juga menghafal agar lebih mudah dan menyenangkan.

Ibu Tanty dan ibu Rubini selaku guru IPS di MTs Negeri 1 Semarang juga berpendapat yang sama bahwa siswa tertarik untuk mengikuti atau memperhatikan pelajaran yang disampaikan oleh guru dengan menggunakan media pembelajaran. Sesuai dengan pernyataan ibu Rubini bahwa ketika menggunakan media couple card dalam materi perubahan sosial siswa cukup memperhatikan dan mau menerima pembelajaran yang diberikan, respon siswa sendiri senang dan bersemangat dalam belajar. Siswa menjadi berani mengungkapkan pendapat sesuai dengan apa yang mereka pahami dan mampu memberikan kesimpulan. Dengan penggunaan media pembelajaran ini secara tidak langsung menumbuhkan karakter yang dapat mempengaruhi personal, emosi, dan sosial siswa.

b. Media yang akan digunakan harus sesuai dengan materi pembelajaran.

Setiap materi pembelajaran memiliki kekhasan dan luas cakupan materi yang dibahas. Media yang digunakan oleh guru hendaknya sesuai dengan materi pembelajaran. Tanpa adanya materi tidak akan berjalan dengan baik. Oleh sebab itu guru yang mengajar pasti mempelajari dan mempersiapkan materi pelajaran yang akan diberikan kepada siswa. Materi menjadi unsur penting dalam penggunaan media pembelaajran.

Ibu Heppy guru IPS SMP N 2 Semarang menyatakan bahwa saat menggunakan media puzzle disesuaikan terlebih dahulu dengan materi yang akan disajikan. Karena tidak semua materi dapat diaplikasikan dengan media puzzle tersebut. Ibu Sri guru IPS di SMP N 2 Semarang juga berpendapat bahwa penggunaan media harus disesuaikan dengan materi. Ibu Sri menjelaskan sebelum pembelajaran dimulai beliau menyiapkan RPP kemudian menentukan media pembelajaran yang disesuaikan dengan materi. Pada saat materi klasifikasi flora dan fauna Indonesia berdasarkan persebarannya beliau menggunakan media berupa mahkota naget, alasan ibu Sri menggunakan media tersebut karena materinya luas, jika tidak menggunakan media pembelajaran seperti mahkota naget, siswa hanya tahu Indonesia, tapi siswa itu tidak mengetahui kedalaman materi Indonesia, maka harus dikolaborasi.

Hal serupa juga dilakukan oleh guru IPS di MTs N 1 Semarang, untuk mendukung materi yang akan diajarkan ibu Tanty dan ibu Rubini memilih media yang sesuai, pada saat materi ASEAN ibu Tanty membuat jam putar dimana media tersebut menyerupai jam dinding yang diberi bendera-bendera yang termasuk negara anggota ASEAN. Dengan penggunaan media jam putar diharapkan siswa dapat lebih mudah dalam memahami dan mengingat materi tersebut. Sedangkan untuk ibu Rubini sendiri saat mengajarkan materi perubahan sosial beliau menggunakan media couple card. 
Penggunaan media dalam pembelajaran harus tepat dan menyesuaikan dengan materi, penggunaan media yang kurang tepat juga akan berpengaruh dan menghambat proses belajar siswa, maka dari itu guru harus pintar dalam menentukan media pembelajaran kepada siswa saat pembelajaran.

c. Media yang digunakan harus memperhatikan efektivitas dan efisiensi.

Media dapat dikatakan efektif apabila media yang digunakan sesuai dengan fungsinya. Adanya media pembelajaran menjadikan materi yang banyak dapat diringkas menjadi singkat dan ditampilkan menggunakan media. Sebagaimana yang dijelaskan ibu Heppy guru IPS SMP N 2 Semarang bahwa dengan menggunakan media puzzle proses pembelajaran menjadi lebih efektif karena membantu siswa memahami materi dengan gambaran nyata bukan konsep atau tulisan-tulisan saja. Karena apa yang kita lihat itu lebih mudah kita cerna dan pahami, sehingga siswa memperoleh pengalaman yang konkret, proses pembelajaran juga jadi menyenangkan. Sebagai guru juga tidak hanya ceramah saat mengajar, sehingga siswa tidak bosan untuk mengikuti pelajaran. Selain itu media ini juga dapat digunakan dimana saja mba.

Hal tersebut juga dirasakan oleh ibu Tanty guru IPS MTs N 1 Semarang mengenai efektivitas media yang digunakan yaitu dengan materi ASEAN yang cukup luas menggunakan media jam putar menjadi lebih efektif. Berbeda halnya dengan ibu Rubini guru IPS MTs N 1 Semarang mengatakan bahwa penggunaan media couple card kurang efektif dikarenakan waktunya terbatas.

Berdasarkan hasil wawancara di atas dapat disimpulkan bahwa kefektifan suatu media sangat berpengaruh dalam proses pembelajaran karena dengan menggunakan media sebagai tolak ukur dalam kefahaman siswa dalam menerima materi pelajaran.

d. Media yang digunakan harus sesuai dengan kemampuan guru dalam mengoperasikannya.

Seiring media yang kompleks terutama media-media yang berbasis teknologi seperti media laptop, LCD dan media elektronik lainnya memerlukan kemampuan khusus dalam mengoperasikannya. Seperti yang dikatakan ibu
Heppy bahwa media secanggih atau sesederhana apapun tidak akan bisa membantu tanpa kemampuan menggunakannya. Hal ini betul-betul harus diperhatikan karena kalau tidak sesuai kemampuan menggunakannya, bukannya menambah kemudahan siswa, malah sebaliknya mempersulit siswa dalam belajar, dengan seperti itu penting sekali bagi guru untuk mengikuti pelatihan / workshop guna meningkatkan kemampuan dalam menggunakan media pembelajaran. Sama halnya dengan guru IPS SMP N 2 Seamarang, Ibu Rubini guru IPS MTs N 1 Semarang mengatakan bahwa apabila tidak sesuai kemampuan dalam menggunakan media tersebut akan mempersulis siswa.

\section{Pengembangan Media Pembelajaran IPS}

Undang-Undang Nomor 14 Tahun 2005 pasal 20 berisi tentang pelaksanaan tugas keprofesionalan guru berkewajiban sebagai berikut: (1) merencanakan pembelajaran, melaksanakan proses pembelajaran yang bermutu, serta menilai dan mengevaluasi hasil pembelajaran, (2) meningkatkan dan mengembangkan kualifikasi akademik dan kompetensi secara berkelanjutan sejalan dengan perkembangan ilmu pengetahuan, teknologi, dan seni, (3) bertindak objektif dan tidak diskriminasi, (4) menjunjung tinggi peraturan undang-undang, hukum dan kode etik guru (5) memelihara dan memupuk persatuan dan kesatuan bangsa. Penjelasan mengenai tugas guru tersebut sudah sangat jelas bahwa guru merencanakan pembelajaran dengan baik dan matang, sehingga dalam pelaksanaan pembelajaran mengaplikasikan pembelajaran yang bermutu. Salah satunya yaitu membuat media pembelajaran untuk menyampaikan materi dalam pembelajaran, media yang dibuat guru akan lebih bagus. Kreativitas guru dalam melakukan pengembangan media pembelajaran ini sangat diperlukan, baik itu secara sederhana ataupun yang lebih modern, semuanya disesuaikan dengan kemampuan dan kebutuhan siswa di sekolah.

a. Kolaborasi dengan teman sejawat

Ibu Heppy adalah guru di SMP N 2 Semarang, beliau sudah mengajar IPS selam 22 tahun, dalam pengembangan media pembelajaran ibu Heppy berkolaborasi dengan 
ibu Sri guru IPS di SMP N 2 Semarang. Berdasarkan hasil wawancara dengan ibu Heppy bahwa kolaborasi yang dilakukan tidak hanya kepada satu guru yang ada di sekolah tersebut, kolaborasi bisa terjadi dengan guruguru pada sekolah yang lain. Misalnya saat mengikuti pelatihan, ibu Heppy dan guru-guru IPS dari sekolah lain saling bertukar informasi khususnya masalah media pembelajaran.

Pernyataan tersebut sama dengan ibu Sri guru IPS SMP N 2 Semarang yaitu biasanya saya dengan guru lain berkolaborasi dalam mengembangkan media pembelajaran. Terlebih lagi dengan guru yang lebih berpengalaman di sekolah ini seperti ibu Heppy. Untuk meningkatkan kualitas diri dan pembelajaran saya juga mengikuti pelatihan-pelatihan yang. diadakan dinas pendidikan, selain mendapatkan ilmu dari pelatihan tersebut, saya juga dapat bertukar informasi mengenai media pembelajaran dengan guru IPS dari sekolah lain.

Berdasarkan hasil wawancara diatas dalam pengembangan media pembelajaran guru IPS di SMP Negeri 2 Semarang melakukan kolaborasi antar guru, kolaborasi yang dilakukan pun tidak hanya dengan guru yang ada di sekolah tersebut, tetapi bisa terjadi pada guru dari sekolah lain. Dengan adanya kolaborasi seorang guru dapat saling bekerjasama, komunikasi, dan sinergi dengan guru yang lain. Proses tersebut yang membentuk suasana dan semangat dalam pengembangan media pembelajaran.

b. Guru mengembangkan media mencari di internet

Penggunaan internet dalam bidang pendidikan sangat dirasakan manfaatnya oleh para guru. Manfaat internet sendiri secara luas dapat memperbaiki kualitas guru. Hal tersebut dirasakan oleh guru IPS MTs N 1 Semarang seperti yang dijelaskan oleh ibu Tanty yaitu "karena saya pribadi belum pernah mengikuti pelatihan dan dari kemenag juga belum pernah mengadakan pelatihan media, adanya internet sangat membantu saya untuk mencari referensi media pembelajaran. Contohnya seperti media jam putar hanya saja media tersebut saya sederhanakan sesuai dengan kelengkapan yang ada di sekolah dan kebutuhan siswa. Sama halnya dengan guru MTs N 1 Semarang, ibu Heppy dan ibu Sri guru IPS SMP N 2 Semarang mengatakan bahwa selain mengikuti pelatihan / workshop media, dalam mengembangkan media guru juga mencari di internet.

Berdasarkan hasil wawancara di atas dapat disimpulkan bahwa kemajuan teknologi di zaman sekarang ini sudah menuntut hampir semua orang untuk berhubungan dengan internet. Tidak bisa dipungkiri banyak sekali manfaat yang sudah diberikan internet. Selain dapat menghemat waktu dengan adanya internet guru semakin mudah dalam mencari referensi dalam pengembangan media pembelajaran.

Guru mengembangkan media dengan memanfaatkan bahan-bahan yang ada di sekolah maupun di lingkungan sekitar

Setiap guru IPS harus mempunyai kreativitas dalam mengembangkan media pembelajaran. Salah satu kreativitas yang dimiliki guru IPS pada SMP N 2 Semarang dan MTs N 1 Semarang dalam mengembangkan media pembelajaran yaitu memanfaatkan bahan-bahan yang ada di lingkungan sekitar untuk membuat media pembelajaran. Para guru berusaha membuat media pembelajaran dengan bahan yang ada untuk membuat media pembelajaran dengan sebaik-baiknya, agar media yang dibuat bisa menjadi media yang menarik dan dapat memberikan pembelajaran yang menyenangkan bagi siswa.

Sebagaimana penjelasan ibu Sri guru IPS SMP N 2 Semarang bahwa dalam mengembangkan media pembelajaran banyak sekali bahan yang mudah diperoleh untuk dijadikan media edukasi anak-anak tanpa harus membeli dengan harga yang mahal, contohnya menggunakan kertas daur ulang seperti media mahkota naget, dengan penggunaan kertas daur ulang juga dapat mengurangi sampah dan menambah keterampilan siswa.

Sama halnya yang terjadi di SMP N 2 Semarang, di MTs N 1 Semarang pun demikian, ibu Tanty menjelaskan dalam pembuatan media jam putar ASEAN saya menggunakan bahan yang sudah tidak terpakai di sekolah maupun yang ada di lingkungan sekitar seperti Styrofoam, kertas bekas dan bambu. Selain tidak memerlukan biaya, yang penting media tersebut dapat bermanfaat dan menyenangkan bagi siswa. 
Berdasarkan wawancara di atas dapat disimpulkan bahwa media pembelajaran yang digunakan tidak selalu dengan harga mahal, bahkan banyak media pembelajaran yang tidak mengeluarkan biaya dalam pembuatannya salah satunya dengan memanfaatkan bahan-bahan yang ada disekitar. Dengan demikian seorang guru yang kreatif bisa terlihat ketika memanfaatkan bahan-bahan sederhana yang bisa dijadikan suatu media di dalam mata pelajaran.

Evaluasi Kebermanfaatan Media Pembelajaran IPS

a. Media dapat memperjelas materi

Media sangat dibutuhkan dalam proses pembelajaran, karena media sebagai alat penyampaian materi, sehingga jika tidak ada media maka materi yang disampaikan abstrak, dan pemahaman siswa terhadap materi akan kurang karena tidak ada bentuk visual dari materi yang diajarkan. Media mutlak dibutuhkan oleh seorang guru dengan cara guru mengemas sedemikian rupa materi pembelajaran agar menjadi materi yang mudah dipahami oleh siswa sehingga tujuan pembelajaran dapat tercapai.

Edgar Dale (Sanjaya, 2009: 164) menjelaskan bahwa "pengalaman belajar seseorang dapat diperoleh melalui proses perbuatan atau mengalami sendiri apa yang dipelajari, proses mengamati dan mendengarkan melalui media tertentu dan proses mendengarkan melalui bahasa". Hal ini semakin konkrit siswa mempelajari bahan pengajaran contohnya melalui pengalaman yang diperoleh siswa. Dalam pemahaman materi siswa di SMP N 2 Semarang dan MTs N 1 Semarang sudah baik. Secara umum media yang digunakan guru dapat mempermudah siswa dalam memahami materi karena siswa terlibat langsung dengan media yang digunakan sehingga siswa dapat memperoleh informasi yang diperlukan.

Dengan demikian penggunaan media media dalam kegiatan belajar mengajar memiliki pengaruh yang besar terhadap alat-alat indera. Terhadap pemahaman isi pelajaran secara nalar dapat dikemukakan bahwa dengan menggunakan media akan lebih menjamin terjadinya pemahaman yang lebih baik pada siswa. siswa yang belajar hanya mendengarkan saja akan berbeda tingkat pemahaman dan lamanya ingatan bertahan dibandingkan dengan siswa yang belajar dengan melihat sekaligus mendengarkan dan melihat.

b. Media menyebabkan motivasi belajar anak meningkat

Media pembelajaran dan guru memiliki peranan penting dalam meningkatkan motivasi belajar siswa di SMP N 2 Semarang dan MTs N 1 Semarang. Hal tersebut disebabkan cara guru mengajar dan media pembelajaran yang digunakan. Dengan menggunakan media pembelajaran ketika proses pembelajaran IPS pengajaran bisa lebih menarik, media dapat diasosiasikan sebagai penarik perhatian, menjadikan proses pembelajaran menjadi lebih interatif dengan begitu bisa meningkatkan kualitas belajar siswa. Keadaan tersebut sesuai dengan pendapat Hamalik (1986) yang dikutip Azhar Arsyad (2010:15) mengemukakan bahwa penggunaan media pembelajaran dalam proses belajar mengajar dapat membangkitkan keinginan dan minat yang baru, membangkitkan motivasi dan rangsangan kegiatan belajar, dan membawa pengaruh-pengaruh psikologis terhadap siswa. Penggunaan media pembelajaran pada orientasi pembelajaran akan sangat membantu keaktifan proses pembelajaran dan pemnyampaian pesan dan isi pada saat itu. Selain membangkitkan motivasi dan minat siswa, media pembelajaran juga dapat meningkatkan pemahaman, menyajikan data dengan baik dan terpercaya.

Siswa di SMP N 2 Semarang dan MTs N 1 Semarang memiliki motivasi belajar pada mata pelajaran IPS karena adanya dorongan dari guru melalui media pembelajaran yang digunakan serta cara mengajar guru yang tidak membosankan sehingga siswa aktif dan antusias serta belajar dengan sungguh-sungguh pada proses belajar mengajar. Dengan demikian media pembelajaran mampu membangkitkan dan membawa siswa ke dalam suasana rasa senang dan gembira dimana ada keterlibatan emosional dan mental. Tentu hal ini berpengaruh terhadap semangat siswa saat belajar dan kondisi pembelajaran yang lebih hidup yang nantinya mengarah kepada 
peningkatan pemahaman siswa terhadap materi ajar.

c. Meningkatnya hubungan interaksi antara guru dan siswa

Media pembelajaran merupakan bagian paling penting dalam proses pendidikan. Media pembelajaran yang sukses dapat dilihat dari aktivitas pembelajaran antara guru dan siswa. Keterlibatan siswa dalam aktivitas pembelajaran dengan menggunakan media pembelajaran merupakan penunjang keberhasilan kegiatan proses belajar mengajar. Siswa yang memiliki perhatian lebih pada mata pelajaran tertentu sehingga dengan sendirinya akan melibatkan dirinya pada proses pembelajaran yang ada.

Sudjana dan Rivai (2010:2) bahwa manfaat media pembelajaran dalam proses pembelajaran siswa lebih banyak melakukan kegiatan belajar sebab tidak hanya mendengarkan uraian guru, tetapi juga aktivitas lain seperti mengamati, melakukan, mendemonstrasikan dan lain-lain. Sesuai dengan pendapat tersebut, interaksi antara siswa dan guru di SMP N 2 Semarang pada proses pembelajaran dengan menggunakan media pembelajaran sudah cukup baik. Hal tersebut salah satunya terlihat bahwa siswa fokus dan memperhatikan penjelasan guru dengan baik dan aktif pada proses disksusi serta aktif bertanya pada guru. Sedangkan interaksi antara siswa dan guru di MTs N 1 Semarang masih kurang dimana siswa memperhatikan penjelasan yang disampaikan oleh guru namun siswa kurang aktif dalam proses pembelajaran.

Dengan demikian media pembelajaran dapat membantu menyalurkan pesan sebagai bentuk interaksi antara dua orang atau lebih. Interaksi yang dimaksud adalah interaksi antara guru dengan siswa. Adanya interaksi yang baik dalam dalam proses belajar mengajar, akan membuat siswa menjadi lebih aktif, sehingga didapatkan hasil yang baik.

\section{SIMPULAN}

\section{Simpulan}

Berdasarkan hasil penelitian kreativitas guru IPS dalam pengembangan media pembelajaran pada SMP Negeri 2 Semarang dan MTs Negeri 1 Semarang dapat ditarik kesimpulan
Penggunaan media pembelajaran IPS pada SMP Negeri 2 Semarang dan MTs Negeri 1 Semarang terlihat dari pemilihan media yang akan digunakan dalam pembelajaran. Pemilihan media tersebut mempertimbangkan banyak faktor, diantarana mudah didapat, tidak mahal, mudah digunakan, relevan dengan materi, diskai siswa, dan tidak memakan waktu banyak. Dalam penggunaan media pembelajaran guru IPS pada SMP Negeri 2 Semarang dan MTs Negeri 2 Semarang memperhatikan prinsip penggunaan media pembelajaran, yaitu media yang digunakan guru harus sesuai dan diarahkan untuk mencapai tujuan pembelajaran, media yang akan digunakan harus sesuai dengan materi pembelajaran, media yang digunakan harus memperhatikan efektivitas dan efisiensi, media yang diguanakan harus sesuai dengan kemampuan guru dalam mengoperasikannya.

Kreativitas guru IPS dalam pengembangan media pembelajaran pada SMP Negeri 2 Semarang dan MTs Negeri 1 Semarang dilakukan melalui kolaborasi dengan teman sejawat, guru mengembangkan media mencari di internet dan guru mengembangkan media dengan memanfaatkan bahan-bahan yang ada di lingkungan.

Evaluasi kebermanfaatan dengan media pembelajaran pada SMP Negeri 2 Semarang dan MTs Negeri 1 Semarang yaitu media dapat memperjelas materi, media menyebabkan motivasi belajar anak meningkat dan media dapat meningkatkan hubungan interaksi antara guru dan siswa.

\section{Saran}

Berdasarkan hasil penelitian dan pembahasan, saran yang dapat disampaikan adalah:

1. Guru dapat meningkatkan kreativitas menggunakan media pembelajaran dengan mengikuti pelatihan dalam pembuatan media pembelajaran.

2. Hendaknya sekolah menambah media pembelajaran yang mendukung proses pembelajaran IPS sehingga guru dapat menjalankan proses pembelajaran secara maksimal 


\section{DAFTAR PUSTAKA}

Abdullah, Ramli. Pembelajaran Dalam Perspektif Kreativitas Guru Dalam Pemanfaatan Media Pembelajaran. (Lantanida Journal Vol. 4 No. 1, 2016).

Afrizal. 2014. Metode Penelitian Kualitatif. Depok: PT Raja Grafindo Persada.

Agung, Iskandar. 2010. Meningkatkan Kreativitas Pembelajaran Bagi Guru. Jakarta: Bestari Buana Murni.

Agustina, 2015. "Kompetensi Pedagogik Guru di SMP Negeri 1 dan 2 Kecamatan Sebaris Kabupaten Padang Pariaman". Dalam Journal administrasi pendidikan, No 1. Hal. 663-759. Agustina, Titik. 2016. "Pengaruh Kreativitas Mengajar Guru Terhadap Prestasi Belajar IPS Kelas VIII MTs egeri Galur Tahun Ajaran 201/201. Journal. Hal 581590.

Arsyad, Azhar. 2005. Media Pembelajaran. Jakarta: PT Raja Grafindo Persada.

Arsad, Azhar. 2013. Media Pembelajaran. Jakarta: Rajagrafindo Persada.

Asmani, Jamal Ma'mur. 2010. Tips Menjadi Guru Inspiratif, Kreatif, dan Inovatif. Yogyakarta:DIVA Press

Daud, Adzalina Mohd. 2012. Creativity in science education. Journal Social and Behavioral Scence. O 59. Hal 467474.

Depdiknas (2008). Panduan Pengembangan Bahan Ajar. Jakarta:Depdiknas.

Endayani, Heni. 2017. Pengembangan Materi Ajar Ilmu Pengetahuan Sosial. Jurnal program studi Pendidikan Ilmu Pengetahuan Sosial, vol 1.

Fauzi Monawati. 2018. Hubungan Kreativitas Mengajar Guru Dengan Prestasi Belajar Siswa. Junal Pesona Dasar, vol.6.

Ginanjar, Asep. 201. Penguatan Peran IPS dalam Meningkatkan Ketrampilan Sosial Peserta Didik. Journal Harmonia. No. 1. Vol 1. Hal 118-126.

Ibrahim, Halil. 2011. An Investigation on Teaching on Teaching Materials Used in Social Stuudies Lesson.
Journal of Education Technology. Vol 20. Hal 36-44.

Indriana, Dina. 2011. Ragam Alat Bantu Media Pengajaran. Jakarta: PT. Diva Press.

Moleong, Lexy J. 2000. Metode Penelitian Kualitatif. Bandung: Remaja Rosdakarya.

Nisa, Aisah Nur Saiddatun. 2017. "Analisis Kesiapan Guru IPS di SMP seKecamatan Bawang Banjarnegara dalam mendukung Implementasi Kurikulum 2013". Journal Harmony. Vol 1. No 1. Semarang : Universitas Negeri Semarang.

Purnomo, Arif. 201. Model Pembelajaran Ilmu Pengetahuan Sosial (IPS) pada pembelajaran IPS SMP egeri 1 Purwantoro Wonogiri". Journal. Surakarta:Universitas Negeri Semarang.

Rusman. 2012. Belajar dan Pembelajaran Berbasis Komputer. Bandung: ALFABETA.

Sanaky, AH. 2013. Media Pembelajaran Interaktifinteraktif. Yogyakarta: Kaukuba Dipantara.

Sanjaya, Wina. 2014. Media Komunikasi Pembelajaran. Jakarta:Kencana Penada Media Group.

Siswoyo, Dwi. 2005. Ilmu Pendidikan. Yogyakarta: UY Press.

Slameto. 2010. Belajar dan Faktor-faktor yang Mempengaruhi. Jakarta: Rineka Cipta. 